\title{
DISTRIBUTION PATTERN OF Anomalocardia brasiliana GMELIN, 1971 (MOLLUSCA, BIVALVIA) IN A TROPICAL COASTAL ECOSYSTEM
}

\author{
Soraya EL-DEIR ${ }^{1}$ \\ Sigrid NEUMANN-LEITÃO ${ }^{2}$ \\ Pedro Augusto M. de C. MELO'
}

Recebido em: 05/04/2009

Aceito em: 10/08/2009

\begin{abstract}
Anomalocardia brasiliana (Gmelin, 1791) (Bivalvia, Veneridae) distribution pattern was studied from September 2006 to June 2007 in the Itamaracá tropical estuarine system in Northeastern Brazil. Three areas were selected and in each one three transects with three equidistant stations were plotted. At each station, four samples were collected with a $0.0626 \mathrm{~m}^{2}$ quadrate. Shell morphometric measurements showed the presence of four size classes, varying from $<10$ to $>20 \mathrm{~mm}$. A total of 56,865 individuals of $A$. brasiliana were collected and the three banks studied showed significant differences in abundance (Kruskal-Wallis-Dunn $p<0.05$ ). Ramalho area presented $49 \%$ of the total collected individuals and the size class 11 to $15 \mathrm{~mm}$ predominated in all sites.
\end{abstract}

Key words: Bivalve mollusk; Anomalocardia brasiliana; Distribution pattern.

\section{RESUMO}

O padrão de distribuição de Anomalocardia brasiliana (Gmelin, 1791) (Bivalvia, Veneridae) foi estudado de setembro/2006 a junho/2007 no ecossistema tropical estuarino de Itamaracá Nordeste do Brasil. Três áreas foram selecionadas e em cada uma foram demarcadas três transeções, com três estações eqüidistantes. Em cada estação foram coletadas quatro amostras com um quadrado de 0,0626 $\mathrm{m}^{2}$. Medições morfométricas da concha permitiram o estabelecimento de quatro classes de comprimento variando de $<10 \mathrm{~mm}$ a $>20 \mathrm{~mm}$. Um total de 56.865 indivíduos de $A$. brasiliana foi coletado e os três bancos estudados apresentaram diferenças significativa entre si em termos de abundância (Kruskal-Wallis-Dunn $\mathrm{p}<0,05$ ). A área Ramalho apresentou $49 \%$ do total dos indivíduos coletados e a classe de tamanho 11 a $15 \mathrm{~mm}$ predominou em todos os locais estudados.

Key words: Molusco Bivalve; Anomalocardia brasiliana; Padrão de distribuição

\section{INTRODUCTION}

Edible species of mollusks are collected extensively for local consumption in Northeastern Brazil, usually by the families of local fishermen; they harvest principally Crassostrea rhizophorae, Tagelus plebeius, Anomalocardia brasiliana, Mytella guyanensis and M. charruana (Rönnbäck 1999).

Shellfish are among the most accessible and valuable food resources available and thus tend to be heavily exploited where they exist. Shellfishing is an activity open to many people, who may freely move in and out of it and a great variety of methods used, ranging from hands and feet to mechanized dredges. Success as a shellfisherman has historically depended heavily on the right to use shellfish beds freely. Some people see shellfishing as unskilled labor that anyone can do (McCay \& Jenks 1997).

These resources are used as food since prehistoric era on the Brazilian Coast near estuaries (Gaspar, 2000). A. brasiliana is an important source of food for many local communities, and it is one of the main sources of income for local people in some Brazilian estuaries (Nishida et al. 2004; Bohers et al. 2008), mainly at Itamaracá

Contatos: ${ }^{1}$ Departamento de Tecnologia Rural - Universidade Federal Rural de Pernambuco

${ }^{2}$ Departamento de Oceanografia, Universidade Federal de Pernambuco 
EL-DEIR; NEUMANN-LEITÃO; MELO. Distribution pattern of Anomalocardia Anomalocardia brasiliana Gmelin, 1971 (Mollusca, Bivalvia) in a Tropical...

estuarine system (Barros et al. 2000), being also used as medicine (Alves \& Souza 2000).

At Itamaracá system, the undervaluation of these mollusks and ecological services generated by mangrove estuarine ecosystems is a major driving force behind the anthropogenic impacts. This trend of undervaluation is partly due to the lack of ecological knowledge (eg. pattern distribution) and a holistic approach among those performing the evaluation (Rönnbäck 1999).

The present study was undertaken to describe the distribution pattern of $A$. brasiliana at Itamaracá estuarine system and to monitor spatial changes in different seasons, to subsidy a sustainable monitoring program. It is hypothesized that the spatialtemporal clam distribution by abundance will help in future studies to envisage the complexity of natural population dynamics and its sustainability.

\section{MATERIAL AND METHODS}

Sampling were carried out at Coroa do Avião (CA), Ramalho (RA) and Mangue Seco (MS) areas at the South area of Itamaracá island estuarine system ( $7^{\circ} 34^{\prime} 00^{\prime \prime}-7^{\circ} 55^{\prime} 16^{\prime \prime} \mathrm{S}$ and $34^{\circ} 48^{\prime} 48^{\prime \prime}-34^{\circ} 52^{\prime} 24^{\prime \prime} \mathrm{W}$ ) in Northeastern Brazil (Fig. 1). In this area The Coroa do Avião sandbank is an ebb-tidal delta with dimensions, about $560 \mathrm{~m}$ length and $80 \mathrm{~m}$ width, being a recent geological formation, which was originated around 1978, and presents evident erosional and depositional processes (Pinto \& Santos 2006). All these areas are used intensively by clams gatherers. Intensive surveys were carried out in September and November 2006, and in January, March, April and June 2007 to assess $A$. brasiliana pattern distribution. Three sampling transects were chosen in each area (CA, RA, MS) and three equidistant stations were selected in each transect. Four replicates of the biota were collected using a quadrate $25 \mathrm{~cm} \times 25 \mathrm{~cm}$ pushed to a depth of about 20 $\mathrm{cm}$ at all sampling sites, totaling 144 samples. After collection, samples were sieved through a $0.5 \mathrm{~mm}$ mesh screen and fixed in $70 \%$ ethanol.

Anomalocardia brasiliana individuals were counted and their shell length measured to the nearest $0.1 \mathrm{~mm}$. Abundance per area per each size class $(<10 \mathrm{~mm}, 11-15 \mathrm{~mm}$, $16-20 \mathrm{~mm},>20 \mathrm{~mm}$ ) were estimated. To test differences between areas a KruskalWallis test was applied followed by a Dunn test $(p<0.05)$.

\section{RESULTS}

A total of 11,083 individuals of Anomalocardia brasiliana were collected in Coroa do Avião (20\%), 26,595 in Ramalho (49\%) and 19,187 in Mangue seco (31\%), all together 56,865 mollusks. Higher abundance was registered to size class 11 to $15 \mathrm{~mm}$, followed by $16-20 \mathrm{~mm}$ size class. Smaller individuals dominated in January in Coroa do Avião sand bank and, during September/2006 in the others bank. The three areas studied presented significant differences in abundance for $A$. brasiliana (Kruskal-Wallis-Dunn $\mathrm{p}<$ $0.05)$. The Ramalho area presented the highest mean abundance $\left(126 \pm 13\right.$ ind $0.0625 \mathrm{~m}^{-}$ ${ }^{2}$ ) and Coroa do Avião the smallest ( $51 \pm 12$ ind $0.0625 \mathrm{~m}^{-2}$ ) (Fig. 2).

A. brasiliana abundance varied from 1400 to 2376 individuals (CA), from 1081 to 6956 individuals (RA) and from 754 to 6404 individuals (CA). The total abundance of $A$. brasiliana (Fig. 3) was higher in June and September/2006, due to a significant higher abundance in RA; and, during this period fisheries activities is less significant than in November/2006 and January/2007 (summer months).

Figures 4, 5 and 6 present the total abundance per station per bank showing that Coroa do Avião presented in general smaller abundances than Mangue Seco and Ramalho. These last two areas had nearly three times more than Coroa do Avião. 
By Principal Coordinates Analysis the proportions of variance expected using the broken-stick model was $65 \%$ for the first 2 axis, thus it can be seen differences between $\mathrm{CA}$ and the others areas (Fig. 7).

\section{DISCUSSION}

Quantification of species spatial-temporal patterns is important for understanding community structure. In tropical marine intertidal communities, clams of the species Anomalocardia brasiliana are important because they are one of the most abundant invertebrates and they play pivotal roles in governing overall human gathering activities.

A. brasiliana is sensible to ecological parameters changes, and there are experiments relating mortality with intense rainfall (Monti et al. 1991, Möueza et al. 1999), that in the studied area is higher from May to August. It seams that the recruitment and growth of $A$. brasiliana is during the dry season, with many juveniles and a high abundance of many individuals with different sizes (Silva et al. 2005, Boehs et al. 2008), and it was during these months that we found higher gathering activities at Itamaracá system. In case of survival, $A$. brasiliana longevity is from 1.5 to 2 years (Pezzuto et al. 2006).

Specific studies with $A$. brasiliana in São Paulo (Brazil) coastal area showed that this species occurred widely, but reached its highest population densities in sites with poorly sorted sediments rich in calcium carbonate and organic matter (Arruda \& Amaral 2003) and no correlation was made with human activities.

Anomalocardia brasiliana is highly tolerant to environmental impacts, being eurythermal, euryhaline, capable of osmoconformation, and resistant to low oxygen levels (Leonel et al 1982). This species can occur in metahaline environment (salinity $>65 \mathrm{ppm}$ ) and estuaries, living in the meso-littoral and infra-littoral until $1.5 \mathrm{~m}$ depth (Brown \& Mclachlan 1990, Möueza et al. 1999, Denadai et al. 2001). In many sand estuaries in Brazil this bivalve finds favorable conditions, opportunistically exploiting the reducing environment, rich in suspended organic particles as shown by Arruda et al. (2003) to São Paulo organic impacted coastal area.

A. brasiliana was the only species which exhibited fast recolonization rates at disturbed sites (Netto \& Lana 1994) showing its high resilience. Hypoxia is considered to be the major stress factor in many enriched areas; superior tolerance to low dissolved oxygen concentrations has often been suggested for indicator species (Pearson \& Rosenberg 1978). Thus, A. brasiliana could be considered an indicator species of low dissolved oxygen and high organic enriched disturbed sites.

The studied areas at Itamaracá ecosystem could be considered as important stock of Anomalocardia brasiliana and a representative population of traditional gatherers (mainly formed by women and their children), that survives fishing these clams, selling or using that as a complementary food. This resource in many regions of the world is used as food since prehistoric era (Gaspar 2000). However, most studies about this species in Brazil has been about their use to monitor a range of chemicals (WallnerKersanach et al. 1994, Pedrosa \& Cozzolino 2001, Martins et al. 2005, Silva et al., 2006), and ethnoecological aspects (Nishida et al. 2006).

\section{ACKNOWLEDGMENT}

We thank the comments and suggestions of Dr. Ralf Schwamborn, Dr. Fernando Porto and Dr. Tâmara Almeida e Silva. We are thankful to the American Journals Experts for editing the English text. 
EL-DEIR; NEUMANN-LEITÃO; MELO. Distribution pattern of Anomalocardia Anomalocardia brasiliana Gmelin, 1971 (Mollusca, Bivalvia) in a Tropical...

\section{REFERENCES}

ALVES, A. G. C.; SOUZA, R. M.. Etnoecologia de um ambiente estuarino no nordeste do Brasil; conhecimento dos mariscos (Mollusca, Bivalvia) por mulheres no Canal de Santa Cruz. Mangrove, Recife. 2000.

ARRUDA, E. P. de; Amaral, A. C. Z. Spatial distribution of mollusks in the intertidal zone of sheltered beaches in southeastern of Brazil. Revista Brasileira de Zoologia, 20: 291-300. 2003

Arruda, E.P.; Domaneschi, O. \& Amaral, A.C.Z. Mollusk feeding guilds on sandy beaches in São Paulo State, Brazil. Marine Biology, 143: 691-701. 2003

Barros, H.M.; Eskinazi-Leça, E.; Macêdo, S. J. \& Lima, T. Gerenciamento participativo de Estuários e Manguezais, Ed. Universitária da UFPE, Recife, Brazil. 2000.

Bohers, G.; Absher, T.M. \& Cruz-Kaled, A. C. Ecologia populacional de Anomalocardia brasiliana (Gmelin, 1791) (Bivalvia, Vereridae) na Baia de Paranaguá, Paraná, Brasil. Boletim do Instituto Pesca, 34: 259 - 270. 2008.

Brown, A.C. \& Mclachlan, A. Ecology of Sandy Shores. Elsevier Science, New York. 1990.

Denadai, M.R.; Amaral, A.C.Z. \& Turra, A. Spatial distribution of mollusks in two anthropogenic mixed sand-rock substrates of São Sebastião Channel, São Paulo State, Brazil. Estuarine Coastal and Shelf Science, 53: 733-743. 2001

Gaspar, M. 2000. Sambaqui: arqueologia do litoral brasileiro, Editora Jorge Zahar, Rio de Janeiro.

Leonel, R.M.V.; Magalhães, A.R.M. \& Lunetta, J.E. Survival rate of Anomalocardia brasiliana (Gmelin, 1791) (Mollusca-Bivalvia) at different levels of salinity. Brazilian Journal of Medical and Biological Research, 5: 337. 1982.

Martins, L.K.P.; Nascimento, I. A.; Fillmann, G.; King, R.; Evangelista, A.J.A.; Readman, J. W. \& Depledge, M. H. Lysosomal responses as a diagnostic tool for the detection of chronic petroleum pollution at Todos os Santos Bay, Brazil. Environmental Research, 99: 387-396. 2005.

Mccay, B.J. \& Jenks Iii, W.P. The importance of shellfisheries to coastal communities. In: MacKenzie, C.L.; V.G. Burrell, A. Rosenfield \& W.L. Hobart. The History, Present condition and future of the Molluscan Fisheries of North and Central America and Europe. Vol. 2, p. 145-155. 1997.

Monti, D.; Frenkiel, L. \& Moueza, M. Demography and growth of Anomalocardia brasiliana (Gmelin) (Bivalvia: Veneridae) in a Mangrove, in Guadalupe (French West Indies).

Journal of Molluscan Sudies, 57: 249-257. 1991

Mouëza, M., Gros, O. \& Frenkiel, L. Embryonic, larval and postlarval development of the tropical clam, Anomalocardia brasiliana (Bivalvia, Veneridae). Journal of Molluscan Studies, 1999, 65: $73-88$.

Netto, S.A. \& Lana, P.C. 1994. Effects of sediment disturbance on the structure of benthic fauna in a subtropical tidal creek of southeastern Brazil. Marine Ecology Progress Series, 106: 239-247.

Nishida, A.K.; Nordi, N. \& Alves, R.R.N. 2004. Abordagem etnoecologica da coleta de moluscos no litoral paraibano. Tropical Oceanography, 32: 53 - 68.

Nishida, A.K.; Nordi,N. \& Alves, R. R. N. 2006. Mollusk Gathering in Northeast Brazil: An Ethnoecological Approach. Human Ecology, 34: 133-145.

Pearson, T.H. \& Rosenberg, R. 1978. Macrobenthic succession in relation to organic enrichment and pollution of the marine environment. Oceanography and Marine Biology. An Annual Review 16: 229-311. 
Pedrosa, L.F.C. \& Cozzolino, S.M.F. 2001. Composição centesimal e de minerais de mariscos crus e cozidos da cidade de Natal/RN. Ciência e Tecnolologia da Alimentação, 21: 154-157.

Pezzuto, P. R.; Resgalla, C.; Abreu, J. G. N. \& Menezes, J. T. 2006. Environmental impacts of the nourishment of Balneário Camboriu beach, SC, Brazil. Journal of Coastal Research, 2: 863-868, Special Issue 39 WIN.

Pinto, T.K.O. \& Santos, P.J.P. 2006. Meiofauna community structure variability in a Brazilian tropical sandy beach. Atlântica, 28(2): 117-127.

Rönnbäck, P. 1999. The ecological basis for economic value of seafood production supported by mangrove ecosystems. Ecological Economics, 29: 235-252.

Silva, C.A.R.E.; Smith, B.D. \& Rainbow, P.S. 2006. Comparative biomonitors of coastal trace metal contamination in tropical South America (N. Brazil). Marine Environmental Research, 61: 439-455.

Silva, E.; Soares-Gomes, A; Fernandes, F. \& Abreu, C. M. 2005. Sandy beach macrobenthos assemblages at an hypersaline coastal lagoon, Lagoa de Araruama, RJ, Brazil. Journal of Coastal Research, Special Issue 42: 265-270.

Wallner-Kersanach, M.; Lobo, S.E. \& Silva, E.M. 1994. Depuration effects on trace metals in Anomalocardia brasiliana (Gmelin, 1791). Bulletin of Environmental Contamination and Toxicology, 52: 840-847. 
EL-DEIR; NEUMANN-LEITÃO; MELO. Distribution pattern of Anomalocardia Anomalocardia brasiliana Gmelin, 1971 (Mollusca, Bivalvia) in a Tropical...

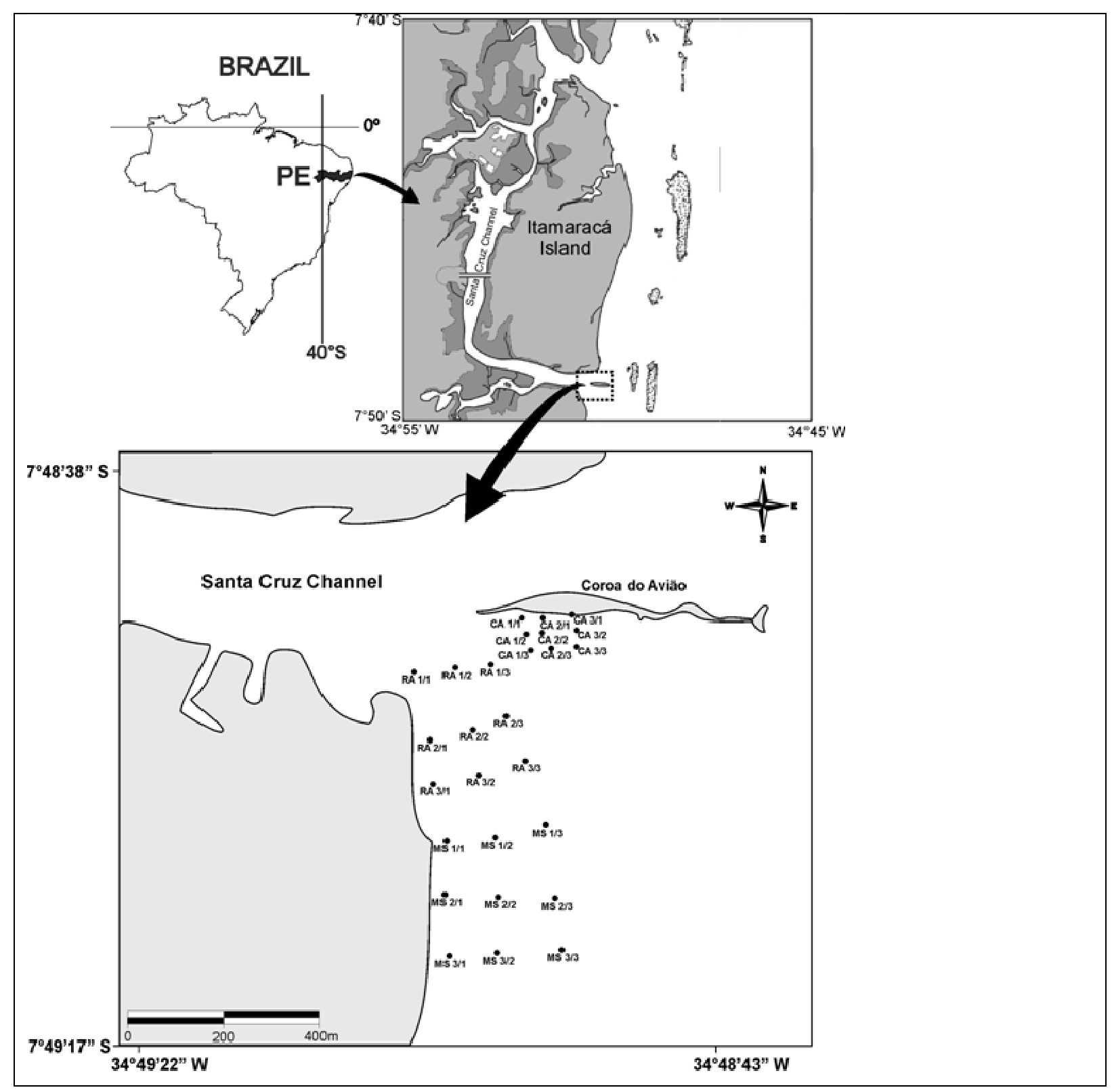

Figure 1 - Estuarine Complex of Santa Cruz Channel, Pernambuco State (Brazil) and Stations in the sand banks of Coroa do Avião (CA), in front of Itamaracá Island, Ramalho (RA) and Mangue Seco (MS), in front of Praia do Capitão, Igarassu, State of Pernambuco (Brazil). 
Tropical Oceanography, Recife, v. 37, n. 1-2, p. 1-12, 2009.

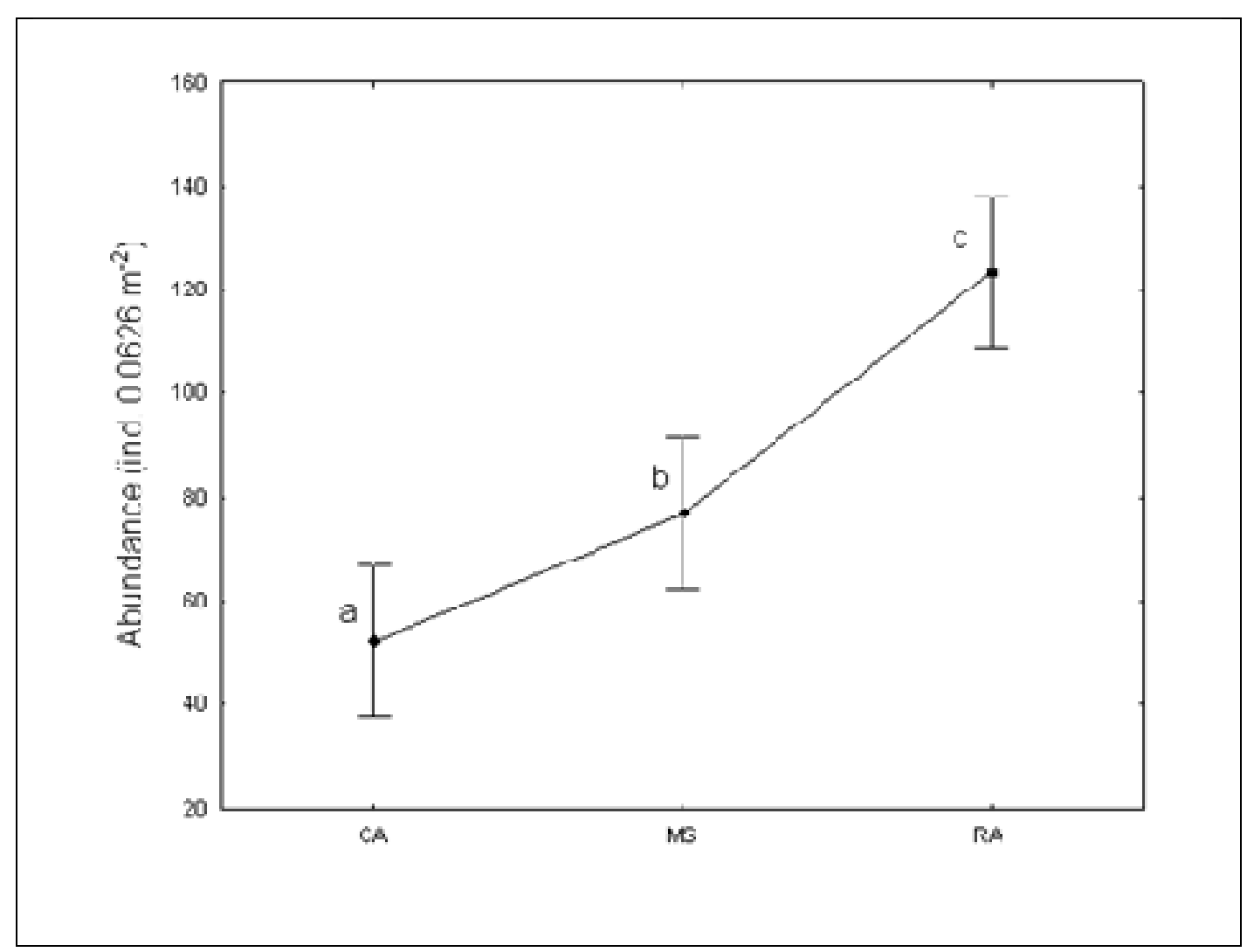

Figure 2 - Mean abundance of Anomalocardia brasiliana per total sand banks at Itamaracá estuarine system (Brazil): CA (Coroa do Avião), MS (Mague Seco), RA (Ramalho). Vertical bars denote 0.95 confidence intervals. 
EL-DEIR; NEUMANN-LEITÃO; MELO. Distribution pattern of Anomalocardia Anomalocardia brasiliana Gmelin, 1971 (Mollusca, Bivalvia) in a Tropical...

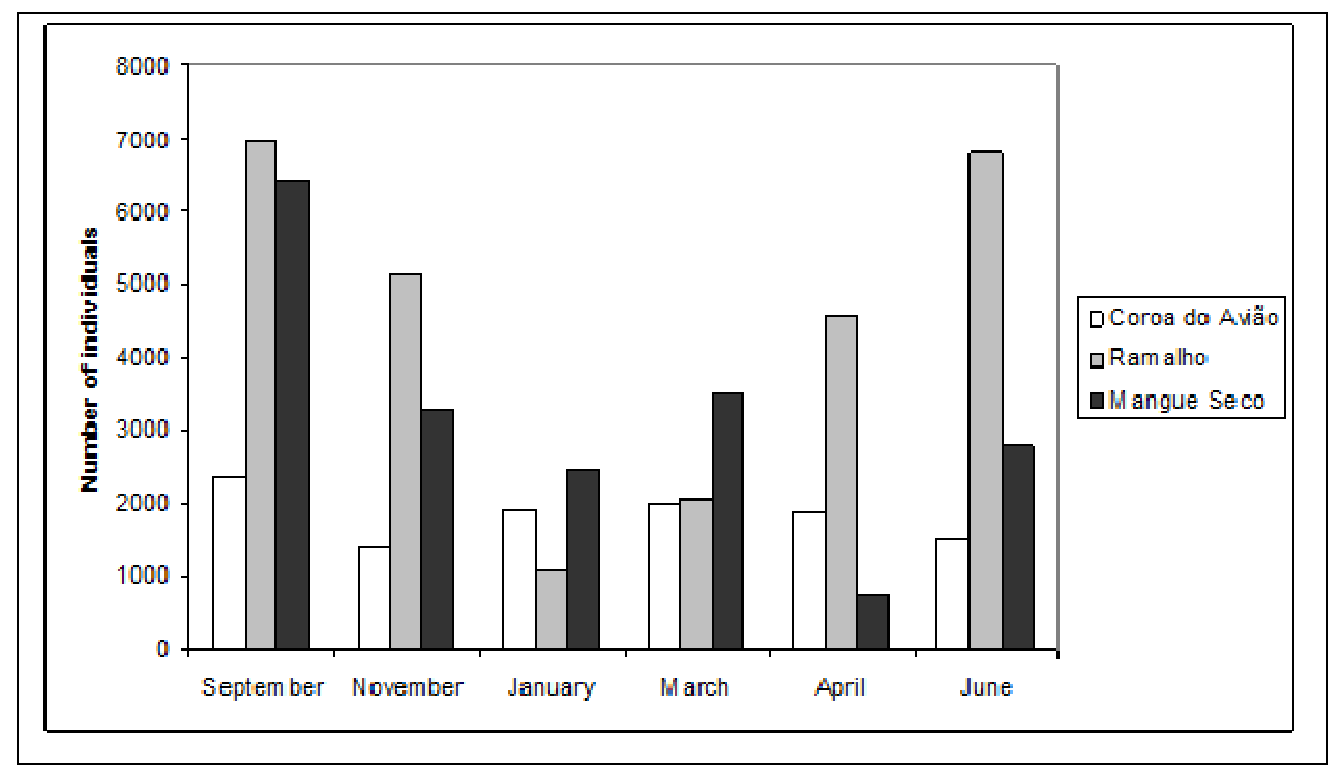

Figure 3 - Total abundance (September, 2006 to June, 2007) of individuals of Anomalocardia brasiliana in three different sand banks, at Itamaracá estuarine system (Brazil). 


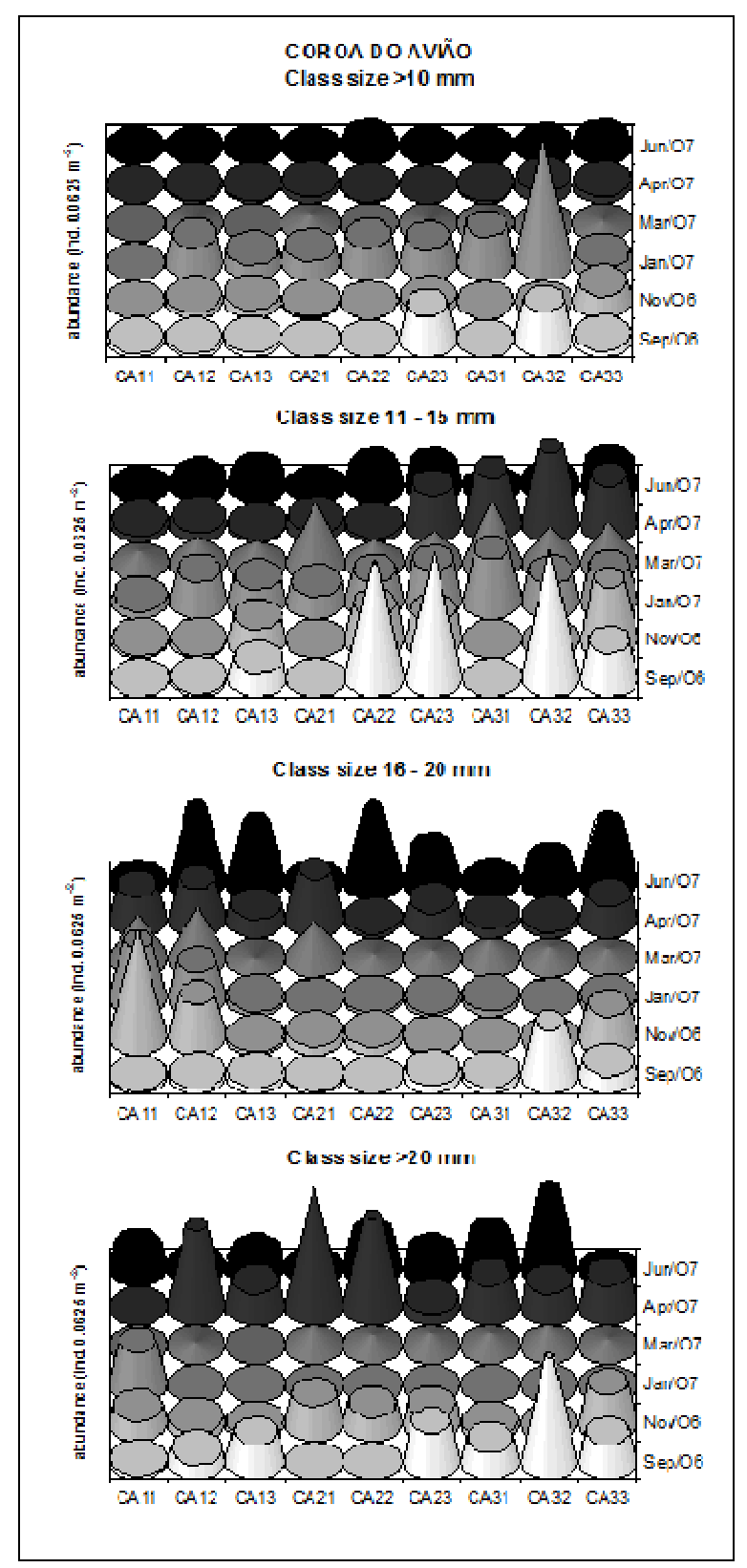

Figure 4 - Temporal abundance per station (September, 2006 to June, 2007) of Anomalocardia brasiliana in Coroa do Avião sand bank, at Itamaracá estuarine system (Brazil). 
EL-DEIR; NEUMANN-LEITÃO; MELO. Distribution pattern of Anomalocardia Anomalocardia brasiliana Gmelin, 1971 (Mollusca, Bivalvia) in a Tropical...

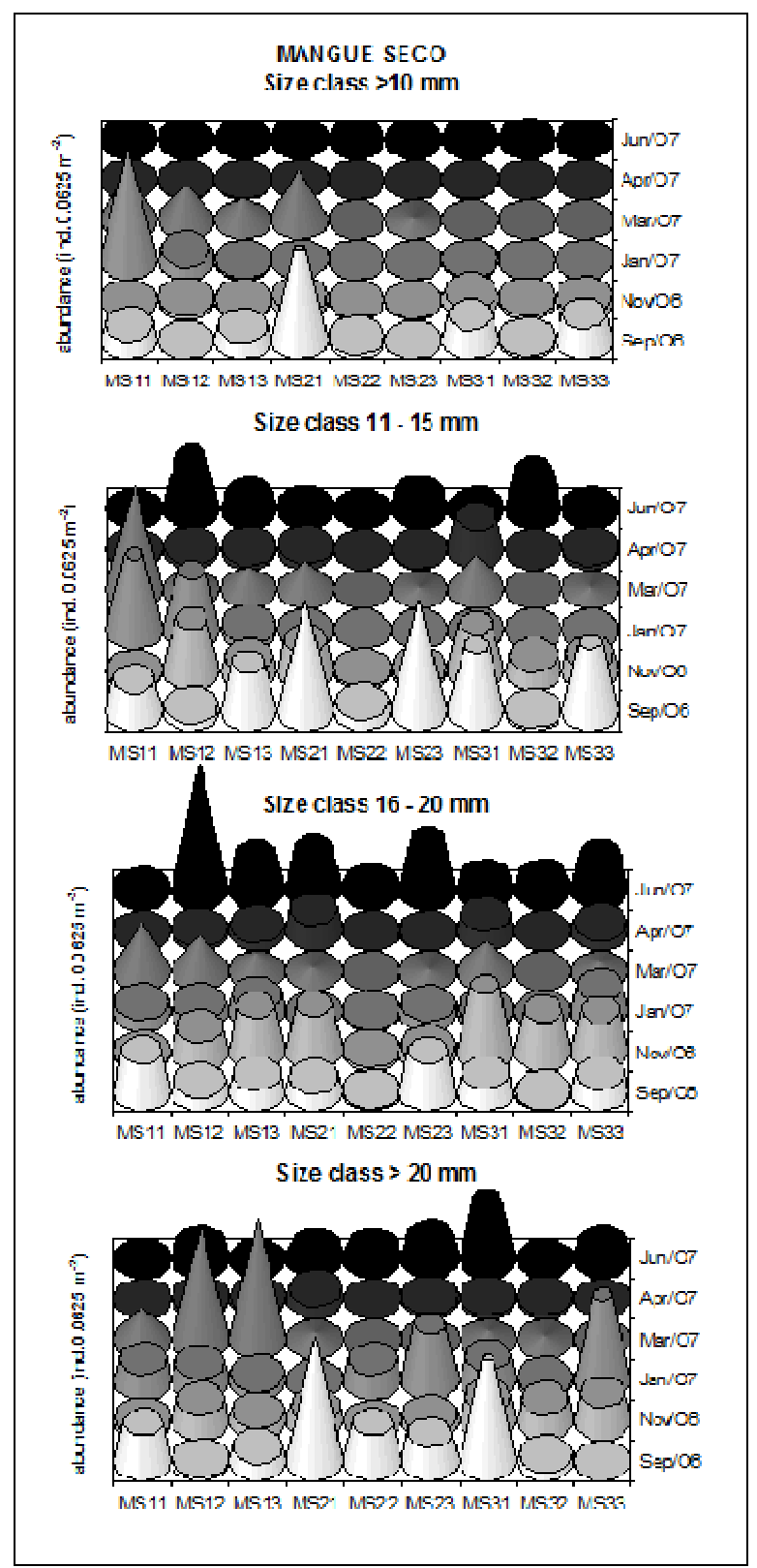

Figure 5 - Temporal abundance per station (September, 2006 to June, 2007) of Anomalocardia brasiliana in Mangue Seco sand bank, at Itamaracá estuarine system (Brazil). 


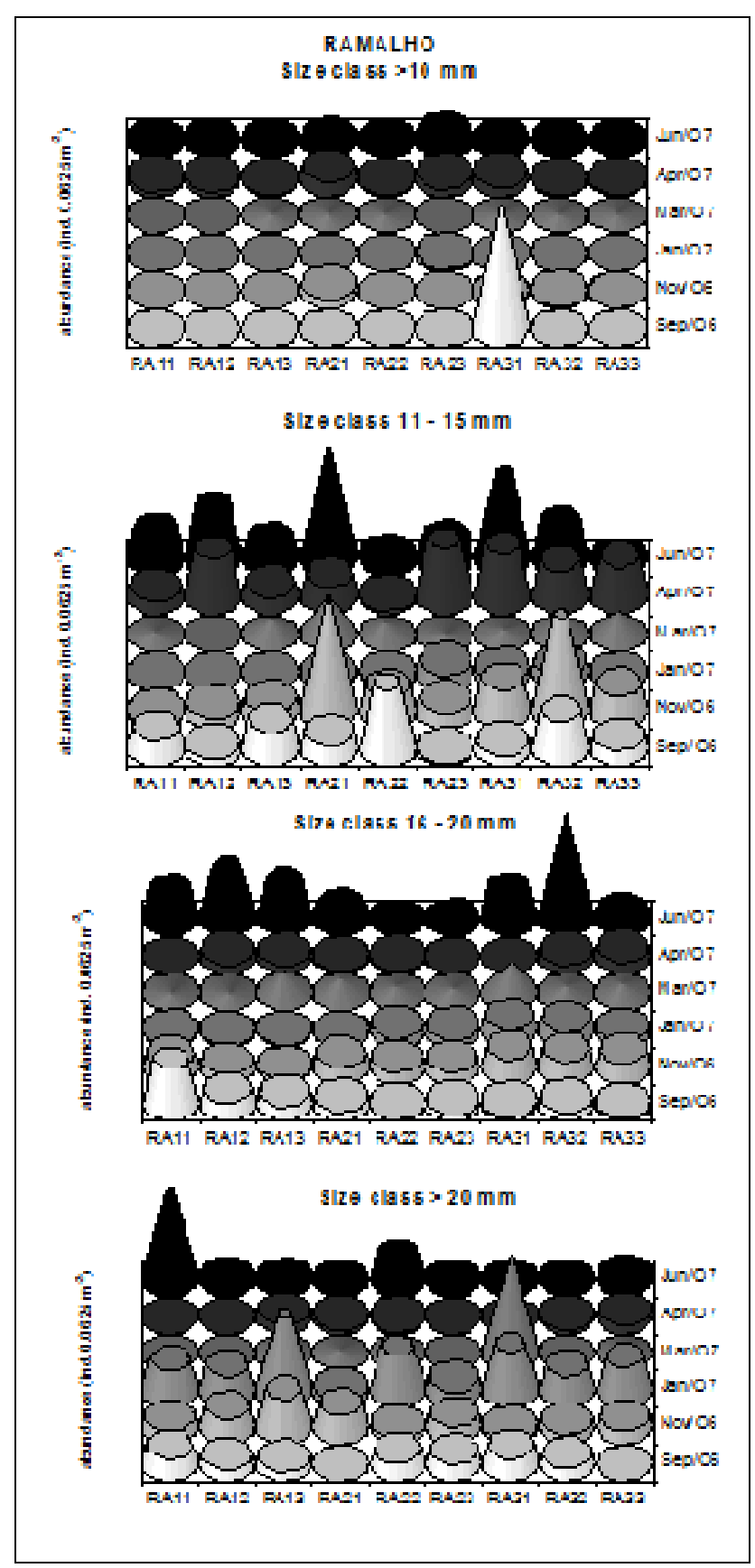

Figure 6 - Temporal abundance per station (September, 2006 to June, 2007) of Anomalocardia brasiliana in Ramalho sand bank, at Itamaracá estuarine system (Brazil). 
EL-DEIR; NEUMANN-LEITÃO; MELO. Distribution pattern of Anomalocardia Anomalocardia brasiliana Gmelin, 1971 (Mollusca, Bivalvia) in a Tropical...

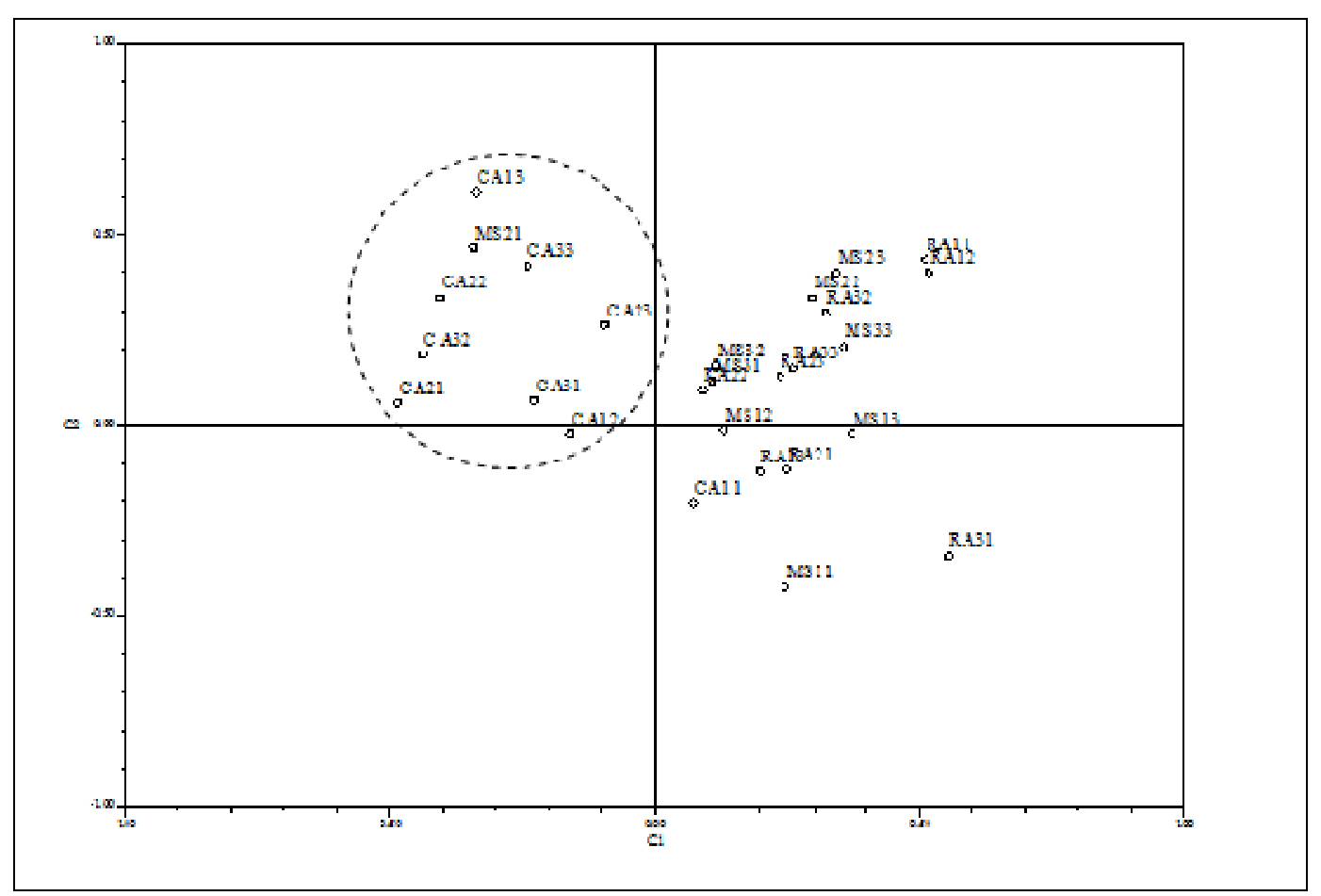

Figure 7 - Principal Coordinates Analysis of all samples at Itamaracá estuarine system, Norheastern Brazil. Bray \& Curtis distance. CA=Coroa do Avião, MS=Mangue Seco, $\mathrm{RA}=$ Ramalho. 